\title{
Project-Based Versus Traditional Lecture Teaching Methods
}

\section{Muhammad Hafeez}

Research Scholar, Allama Iqbal Open University, Islamabad, Pakistan. mh9589041@gmail.com

\begin{tabular}{ll}
\hline Article History & Received : January 9th 2021 \\
& Revision : Marchy $13^{\text {th }} 2021$ \\
& Publication : June 30th 2021 \\
\hline
\end{tabular}

\begin{abstract}
To compete the world in $21^{\text {st }}$ century, it is necessary to adopt the modern learning strategies like inquiry-based, project-based, problem-based. The traditional learning strategies are no viable now to improve the learning skills of the learners. A review of previous studies on traditional lecture-based and project-based learning strategies has been conducted to evaluate the effectiveness of both learning strategies. The learning outcomes and statistical results of 15 previous published articles have selected for this review study. The learning outcomes and statistical results of previous literature indicated that all the studies showed the significant improvement in the learning and cognitive skills of the learners. The effectiveness of project-based teaching strategy in various educational levels are also described in the study.
\end{abstract}

Key Words: Critical Thinking Skills; Effective Teaching; Engagement; Instructors; Learning Strategies

\section{INTRODUCTION}

Learning is a fundamental element of education and plays a vital role in the development of a state (Hafeez et al., 2020). The most important challenge in the educational process is the selection of suitable and effective teaching methods to make the learning process useful and to develop the critical thinking skills in the learners (Senthamarai, 2018; Tavoosy \& Jelveh, 2019). Two important factors to develop the critical thinking skills among the learners are (i) strategy adopted by the instructor (ii) dynamic engagement of learners in learning process (Nelson, 2017). In the teachinglearning process, the instructor must act as a guider instead of knowledge transfer (Molbaek, 2018). According to (Palis \& Quiros, 2014) some important principles for useful learning are (i) learning becomes useful when new knowledge is connected with previous knowledge (ii) The students apply previous knowledge to construct new knowledge (iii) The learning must consist of the strategies to increase the cognitive skills of the learners (iv) All the learners must be engaged in the learning process (v) The learning process must increase the motivation and confidence of the learners.

Various teaching methods like traditional lecture, discussion, project based are discussed in the literature (Farashahi \& Tajeddin, 2018; Usarov, 2019; Yusupov, 2020). The most useful teaching strategy to increase the critical thinking is the small group 
discussion teaching method as concluded by the various studies (Bidabadi, et al., 2016; Yli-Panula et al., 2018; Sivarajah et al., 2019; Strubbe et al., 2020). The traditional lecture method is a one-way conversation in which an instructor delivers the information before the audience (Gholami et al., 2016). After the lecture, the instructor gives notes and assign some tasks as homework (Gregorius, 2017). In traditional lecture teaching methods, no feedback session for the learners is conducted (Almanasef et al., 2020). Generally, very little conversation happens between the learners and instructors (Sarihan et al., 2016). The learners receive passive strategy of learning (Maqbool et al., 2018). The Pictorial view of Traditional learning is shown in figure 1.

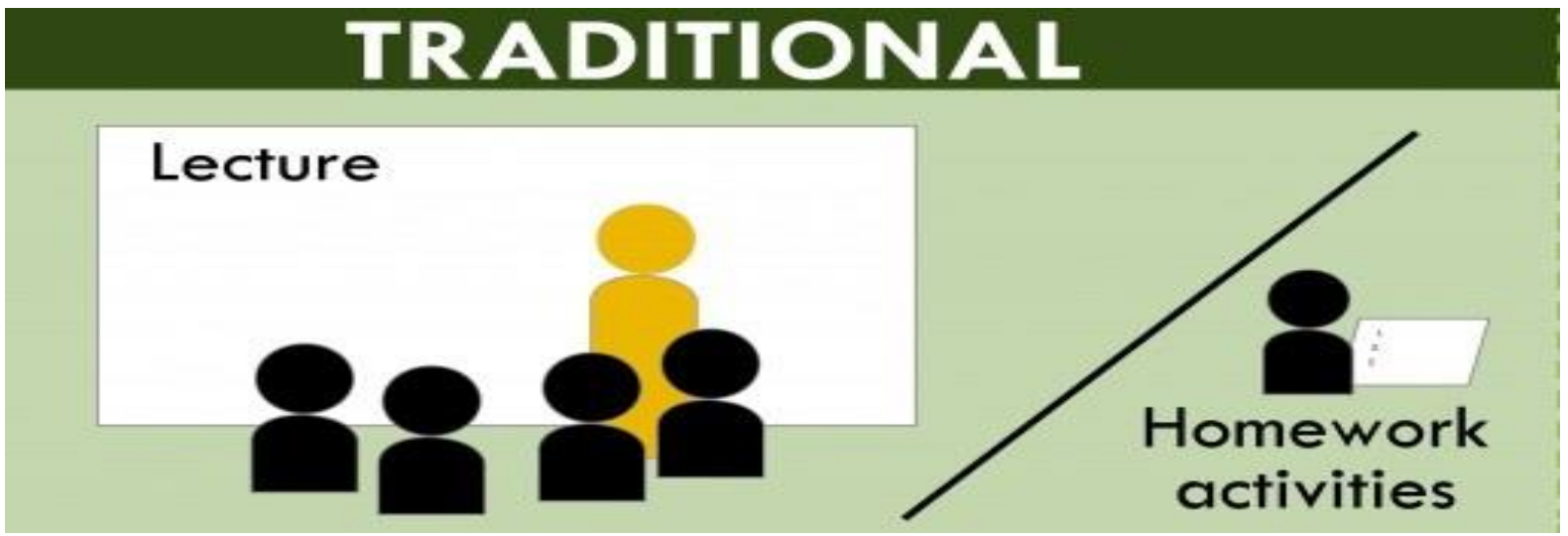

Figure.1: Pictorial Concept of Traditional Learning Method

The Project-Based teaching- learning strategy is a learner-centred instructional approach that is based on three constructivist learning principles (i) learners are engaged actively (ii) learning process is context specific (iii) Goals are achieved by sharing the knowledge between the learners (Kubiatko \& Vaculová, 2011). The project-based learning is also called the inquiry-based learning where the course content is provided by questions and problems related to the real-world context (Al-Balushi \& Al-Aamri, 2014) that leads to useful learning practices (Kwon et al., 2014). The project-based learning strategy has connections with other learning strategies like inquiry-based and problem-based. The main focus in these learning strategies are to share the knowledge in the group (Anazifa \& Djukri, 2017). The freedom of work and challenges that the learners face in the project-based learning are the key elements for the active involvement of the learners and to develop the higher order thinking skills (Kolmos \& Graaff, 2014). In project-based learning strategy, higher order thinking skills and cognitive skills are judged by solving the real-life problems (Brassler \& Dettmers, 2017). The essential elements in project-based learning are shown in figure 2. 


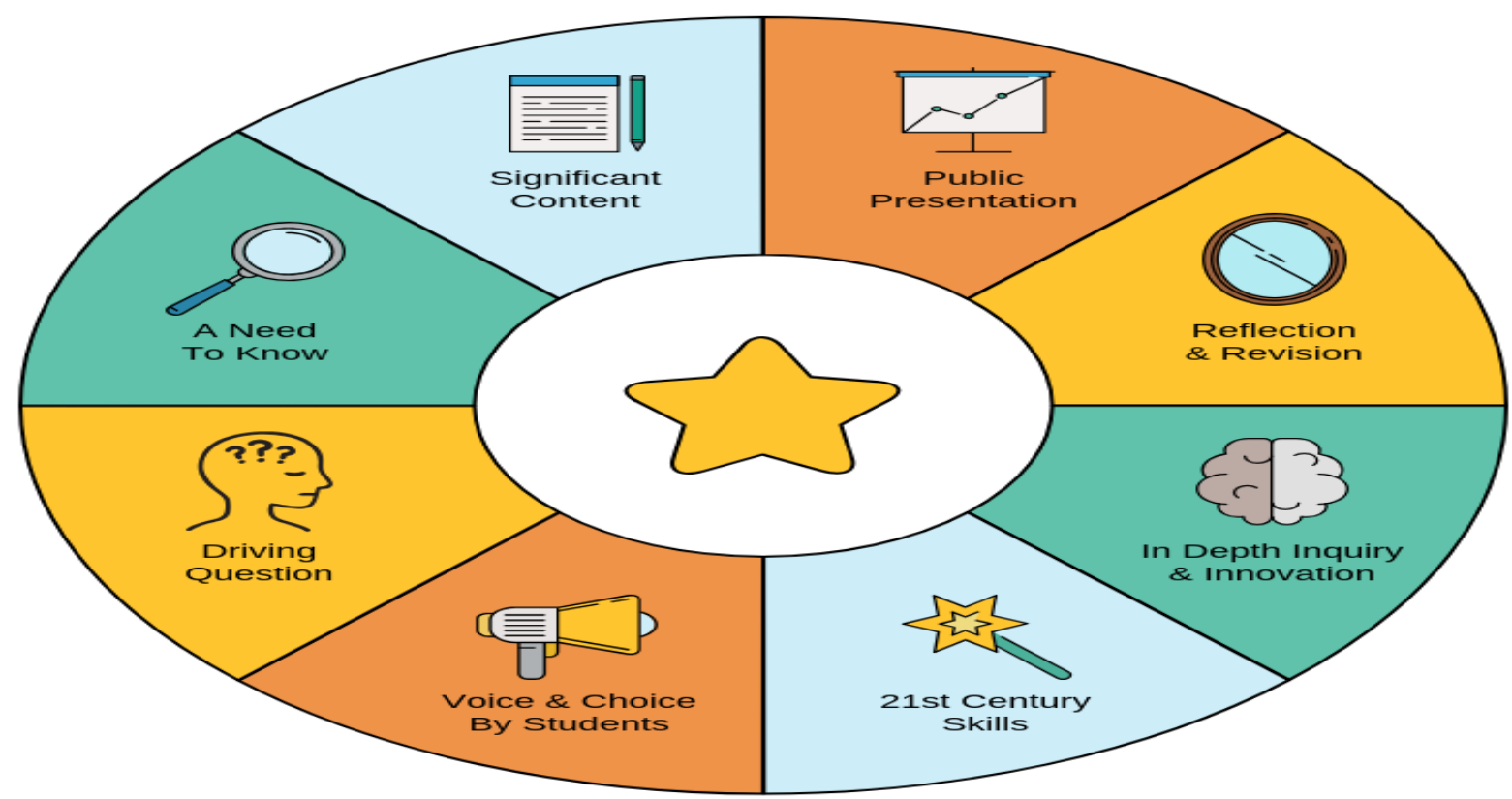

Figure.2: Essential Elements in Project-Based Learning

Affandi \& Sukyadi, (2016) argued that project-based learning helps in promoting the self-regulated learning and conceptual learning. The knowledge is acquired in a systematic way by integration of $21^{\text {st }}$ century digital tools. The whole learning process is documented in project-based learning (Barak, 2012). The learners become intrinsically confident and motivated by setting their goals through a proper planning and collaboration skills in project-based learning. This learning strategy has been applied in various educational context ranging from primary and secondary schools up to higher education (Sari, 2018; Naji et al., 2020).

The $21^{\text {st }}$ learning requirements have been changed from the $20^{\text {th }}$ century. Now the students have to compete with different real-life problems in the society. Various problems-solved learning strategies have been applied in various disciplines in different educational context (De-Graaff et al., 2007; English \& Kitsantas, 2013; Desnylasari et al., 2016; Pinter \& Cisar, 2018; Mann et al., 2020). The purpose of this study is to review the traditional lecture and project-based learning strategies in various educational context.

\section{LITERATURE REVIEW}

For many decades, the teachers have applied traditional learning strategy in classrooms and the learners followed it with homework. The traditional learning strategy makes the students passive and the project-based learning strategy makes the students active and creators. The information becomes valuable when the learners actively participate in learning process. Many instructors and researchers including (Kizkapan \& Bektas, 2017; Nainggolan et al., 2020) concluded that most of the teachers had moved away from the traditional learning strategy as this learning strategy proved to be ineffective for the students in present learning scenario (Saira et al., 2020). The project- 
based learning strategy was an important phase in the learning process. It is one of the most effective learning strategies. The project-based leaning strategy involves the problem-solving contents to work on the project. The results of the knowledge obtained by working on the project are then shared to resolve the target problem (Chen \& Yang, 2019). The differences between traditional learning strategy and project-based learning strategy is illustrated in table 1.

Table.1: Differences between traditional and project-based learning strategies

\begin{tabular}{cll}
\hline Sr.No. & Traditional Learning Strategy & Project-based learning strategy \\
\hline 1 & Face to face learning & Learning may be online \\
\hline 2 & Usually, large group of learners & Small group of learners \\
\hline 3 & $\begin{array}{l}\text { Instructors delivers all the } \\
\text { information }\end{array}$ & $\begin{array}{l}\text { Instructor guided and Self-regulated } \\
\text { Learning }\end{array}$ \\
\hline 4 & No feedback session & Feedback and Presentation session \\
\hline 5 & Passive Learning & Active Learning \\
\hline
\end{tabular}

The project-based learning must be concentrated on the solution of the driving questions and solution is closely related to the reality. The characteristics of ProjectBased learning are shown in figure 3.

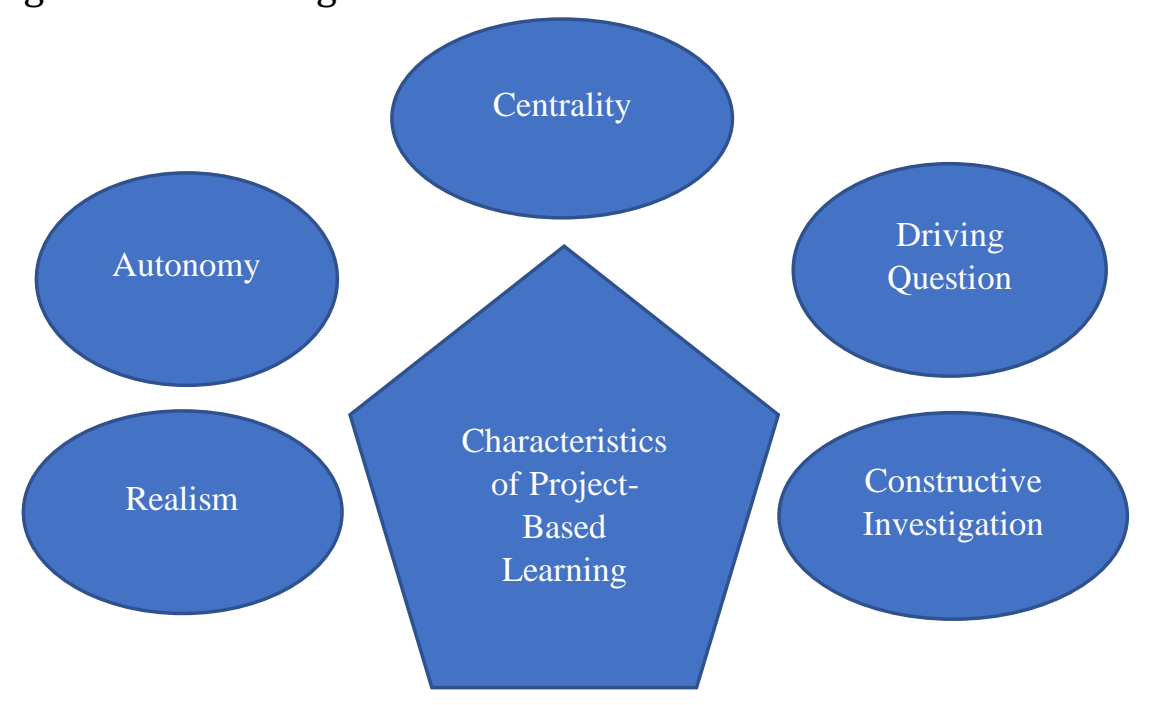

Figure.3: Characteristics of Project-Based Strategy

\section{Effectiveness of Project-Based Strategy in Various Educational Level}

A lot of studies have been conducted to evaluate the effectiveness of Project-Based teaching- learning strategy in various educational levels from primary to higher education (Chu et al., 2017; Balemen \& Keskin, 2018; Ulya et al., 2020). The effectiveness of project-based teaching- learning strategy in various disciplines and educational levels is discussed in the following lines: 


\section{Primary Educational Level}

Habok, (2015) conducted a research to evaluate the effectiveness of Project-Based teaching- learning strategy on the learners of a primary school. Two groups (Experimental and Control) were made for the study. The learners of control group were taught with project-based and experimental group with traditional lecture based. The results of the study concluded that project-based learning strategy significantly improved the critical thinking and confidence skills of the learners. Moreover, the learner's engagement was also improved significantly. Kaldi et al., (2011) directed a quasiexperimental research to indicate the effectiveness of project-based strategy in a primary school of Greece. The results of research indicated that project-based learning strategy improved the learning and knowledge development skills of the learners. The study also revealed that project-based learning strategy also increases the motivation and attitudes towards the group learning environment. Karaçalli and Korur, (2014) conducted a study in Turkey to evaluate the effectiveness on $4^{\text {th }}$ grade science learners. The results of the study indicated a significantly improvement in the academic achievement and retention of information for the learners learned by project-based learning strategy. So, from the literature it can be determined that the project-based learning strategy is an effective way of learning.

\section{Secondary Educational Level}

In a quasi-experimental research conducted by (Al-Balushi and Al-Aamri ,2014) on $11^{\text {th }}$ grade female learners in Oman, the researchers determined that project-based teaching-learning strategy significantly improved the knowledge of the learners in Environmental Science course. Hernández-Ramos \& Paz, (2009) proposed a research to evaluate the effectiveness of project-based teaching-learning strategy on the $8^{\text {th }}$ grade learners in United States of America in History course. The consequences of the study indicated the project-based learning strategy improved the learner's engagement and academic achievements as compared to the learners learned by traditional learning strategy. The project-based learning strategy also improved the student's knowledge level.

Hsu et al., (2016) carried out a quasi-experimental research in United States of America to explored the effectiveness of project-based teaching-learning strategy on $7^{\text {th }}$ grade learners in graph-oriented course. The results of the study indicated that there was an improvement in the knowledge content and student's participation levels by projectbased learning strategy. Geier et al., (2008) described in another study in United States of America on $7^{\text {th }}$ and $8^{\text {th }}$ grade leaners that the learners that involved in project-based learning strategy in Science course has successfully improved the engagement and information level of the learners as compared to the traditional learning approach. 


\section{Higher Educational Level}

A lot of researches have been done to evaluate the usefulness of project-based teaching-learning strategy in higher education in various countries (Bell, 2010; Lee et al., 2014; Balemen \& Keskin, 2018; Tang et al., 2020).

Demian et al., (2016) directed a research to evaluate the effectiveness of projectbased teaching-learning strategy in engineering in UK. The consequences of research indicated that project-based teaching learning strategy significantly improved the problem-solving abilities of the learners. Fernandes et al., (2014) directed a study to evaluate the usefulness of project-based learning by following Powell and Weenk, (2003) model in a Portugal university. The results indicated that project-based learning significantly improved the learner's engagement in the learning process. Gibbes \& Carson, (2014) investigated in a study that project-based teaching-learning strategy is an effective method of learning in higher education especially in Engineering.

The outcomes of the studies reviewed in this article are shown in table 2 . The review shows that all the studies selected for the review indicated significant improvement in engagement and learning process of the learners.

\section{Table.2: The Outcomes of the Studies Reviewed in this Article}

\begin{tabular}{|c|c|c|c|}
\hline Reference & Class & Subject & Outcomes \\
\hline $\begin{array}{l}\text { Johnson \& } \\
\text { Ulseth, } \\
(2014)\end{array}$ & $\begin{array}{l}\text { Undergraduate } \\
\text { Engineering }\end{array}$ & Miscellaneous & $\begin{array}{l}\text { The Project-Based teaching- } \\
\text { learning strategy has a positive } \\
\text { impact on the student academic } \\
\text { achievement. }\end{array}$ \\
\hline $\begin{array}{l}\text { Johnson et al., } \\
\text { (2015) }\end{array}$ & $\begin{array}{l}\text { Undergraduate } \\
\text { students }\end{array}$ & $\begin{array}{l}\text { Physics, } \\
\text { statistics, } \\
\text { professionalism }\end{array}$ & $\begin{array}{l}\text { Significant improvement in } \\
\text { academic grades of different } \\
\text { subjects has been shown by the } \\
\text { learners by project-based learning }\end{array}$ \\
\hline $\begin{array}{l}\text { Sultana \& } \\
\text { Zaki, (2015) }\end{array}$ & $\begin{array}{l}\text { College } \\
\text { Students }\end{array}$ & English & $\begin{array}{l}\text { The project-based learning } \\
\text { strategy successfully improved } \\
\text { the English learning skills of the } \\
\text { learners }\end{array}$ \\
\hline $\begin{array}{l}\text { Lisa et al., } \\
\text { (2018) }\end{array}$ & $\begin{array}{l}\text { College } \\
\text { Students }\end{array}$ & $\begin{array}{l}\text { Statistics } \\
\text { course }\end{array}$ & $\begin{array}{l}\text { The students achieved better } \\
\text { critical thinking and confident } \\
\text { skills by following project-based } \\
\text { learning strategy. }\end{array}$ \\
\hline $\begin{array}{l}\text { Carter, } \\
(2016)\end{array}$ & $\begin{array}{l}\text { Undergraduate } \\
\text { Students }\end{array}$ & Mathematics & $\begin{array}{l}\text { The outcomes of study showed } \\
\text { that Project-Based teaching- } \\
\text { learning strategy is an effective } \\
\text { learning strategy to increase the }\end{array}$ \\
\hline
\end{tabular}




\begin{tabular}{|c|c|c|c|}
\hline & & & $\begin{array}{l}\text { problem-solving and critical } \\
\text { thinking abilities of learners. }\end{array}$ \\
\hline $\begin{array}{l}\text { Chidthachack } \\
\text { et al., (2013) }\end{array}$ & $\begin{array}{l}\text { Undergraduate } \\
\text { students }\end{array}$ & $\begin{array}{l}\text { Engineering } \\
\text { course }\end{array}$ & $\begin{array}{l}\text { The learners engaged more in } \\
\text { Project-Based learning as } \\
\text { compared to the traditional } \\
\text { learning. }\end{array}$ \\
\hline $\begin{array}{l}\text { Jaeger et al., } \\
(2020)\end{array}$ & $\begin{array}{l}\text { Undergraduate } \\
\text { students }\end{array}$ & $\begin{array}{l}\text { Engineering } \\
\text { Courses }\end{array}$ & $\begin{array}{l}\text { Project-based learning strategy } \\
\text { improved the critical thinking } \\
\text { skills of the learners in the } \\
\text { engineering courses. }\end{array}$ \\
\hline $\begin{array}{l}\text { Worry, } \\
\text { (2011) }\end{array}$ & $\begin{array}{l}\text { 10th grade } \\
\text { students }\end{array}$ & $\begin{array}{l}\text { Geometry } \\
\text { course }\end{array}$ & $\begin{array}{l}\text { The consequences of the study } \\
\text { showed that Project-Based } \\
\text { learning strategy was a best } \\
\text { strategy for active learning. }\end{array}$ \\
\hline $\begin{array}{l}\text { Sawyer, } \\
(2013)\end{array}$ & $\begin{array}{l}\text { Elementary } \\
\text { students }\end{array}$ & English Course & $\begin{array}{l}\text { Project-based learning improved } \\
\text { the comprehension and language } \\
\text { skills of the learners. }\end{array}$ \\
\hline $\begin{array}{l}\text { Deitering, } \\
(2016)\end{array}$ & $\begin{array}{l}4 \text { th grade } \\
\text { students }\end{array}$ & General Science & $\begin{array}{l}\text { Project-based learning is an } \\
\text { effective and significant way of } \\
\text { learning. }\end{array}$ \\
\hline $\begin{array}{l}\text { Overholt, } \\
\text { (2017) }\end{array}$ & 6 th grade & Social Sciences & $\begin{array}{l}\text { The leaners taught through } \\
\text { Project-Based strategy scored } \\
\text { higher grades as compared to the } \\
\text { traditional lecture strategy. }\end{array}$ \\
\hline $\begin{array}{l}\text { Yao et al., } \\
\text { (2019) }\end{array}$ & $\begin{array}{l}\text { Middle school } \\
\text { students }\end{array}$ & $\begin{array}{l}\text { Inheritance and } \\
\text { Genetics course }\end{array}$ & $\begin{array}{l}\text { The learners in Project-Based } \\
\text { learning group secured higher } \\
\text { scores than the group learned by } \\
\text { traditional learning strategy. }\end{array}$ \\
\hline $\begin{array}{l}\text { Somani \& } \\
\text { Rizvi, (2018) }\end{array}$ & $\begin{array}{l}\text { 8th grade } \\
\text { students }\end{array}$ & English & $\begin{array}{l}\text { The research indicated a } \\
\text { significant improvement in the } \\
\text { learning process by Project-Based } \\
\text { learning. }\end{array}$ \\
\hline $\begin{array}{l}\text { Armstrong- } \\
\text { Grodzicki, } \\
\text { (2013) }\end{array}$ & High School & $\begin{array}{l}\text { English } \\
\text { Language } \\
\text { Course }\end{array}$ & $\begin{array}{l}\text { The Project-Based learning } \\
\text { strategy improved the English } \\
\text { language reading and writing } \\
\text { skills of the learners. }\end{array}$ \\
\hline $\begin{array}{l}\text { Tortorella \& } \\
\text { Cauchick- } \\
\text { Miguel, } \\
\text { (2018) }\end{array}$ & $\begin{array}{l}\text { Postgraduate } \\
\text { Students }\end{array}$ & $\begin{array}{l}\text { Engineering } \\
\text { Manufacturing } \\
\text { course }\end{array}$ & $\begin{array}{l}\text { Project-Based learning approach } \\
\text { significantly improved the } \\
\text { problem-solving abilities of the } \\
\text { learners. }\end{array}$ \\
\hline
\end{tabular}


In table 2, most of the studies shown that project-based learning is an effective and useful learning strategy in all the disciplines and in all educational levels.

\section{Advantages in Implementing Project-Based Learning}

According to (Stanescu, 2017), some of the advantages in implementing ProjectBased learning strategy are (i) Increases learner's motivation level (ii) Improves learner's academic achievements (iii) Increases student's engagement in the learning process (iv) Increases communication skills (v) Improves research skills (vi) Project-Based learning looks like a fun learning (vii) improves creativity level of the learners (viii) Improves critical thinking skills

\section{Challenges in Implementing Project-Based Teaching- Learning Strategy}

According to (Zafirov, 2013), the challenges in implementing project-based teaching-learning strategy are (i) Project-Based learning strategy is difficult to apply in a large group of class (ii) The instructors face difficulty in improving the motivational level by implementing project-based learning in large class as it becomes difficult to concentrate on all the learners (iii) It becomes difficult for cooperative learning in a large group of class.

\section{Solutions for Challenges}

According to (Harris, 2015) the possible solutions of the challenges in implementing project-based teaching-learning strategy are (i) For implementing the project-based learning, the class must be kept small up to 30 learners (ii) Learners have the ability to understand the project requirements (iii) Learners should cooperate with each other for cooperative learning. The statistical outcomes of various studies revised in this article are illustrated in table 3. 


\begin{tabular}{|c|c|c|c|c|c|}
\hline References & $\begin{array}{l}\text { Teaching } \\
\text { Method }\end{array}$ & Mean & SD & p & Remarks \\
\hline \multirow{2}{*}{$\begin{array}{l}\text { Johnson \& Ulseth, } \\
\text { (2014) }\end{array}$} & Lecture & 5.34 & 1.32 & \multirow[t]{2}{*}{0.0001} & \multirow[t]{2}{*}{ Significant } \\
\hline & Project & 7.26 & 1.09 & & \\
\hline \multirow[t]{2}{*}{ Johnson et al., 2015} & Lecture & 3.92 & 0.54 & \multirow[t]{2}{*}{0.0003} & \multirow[t]{2}{*}{ Significant } \\
\hline & Project & 4.23 & 0.31 & & \\
\hline \multirow{2}{*}{$\begin{array}{l}\text { Sultana \& Zaki, } \\
\text { (2015) }\end{array}$} & Lecture & 17.31 & 5.21 & \multirow[t]{2}{*}{0.00001} & \multirow[t]{2}{*}{ Significant } \\
\hline & Project & 19.20 & 4.72 & & \\
\hline \multirow[t]{2}{*}{ Lisa et al., (2018) } & Lecture & 2.79 & 0.42 & \multirow[t]{2}{*}{0.0004} & \multirow[t]{2}{*}{ Significant } \\
\hline & Project & 3.12 & 0.21 & & \\
\hline \multirow[t]{2}{*}{ Carter, (2016) } & Lecture & 7.30 & 1.93 & \multirow[t]{2}{*}{0.0005} & \multirow[t]{2}{*}{ Significant } \\
\hline & Project & 8.19 & 1.29 & & \\
\hline \multirow{2}{*}{$\begin{array}{l}\text { Chidthachack et al., } \\
\text { (2013) }\end{array}$} & Lecture & 7.32 & 1.87 & \multirow[t]{2}{*}{0.0003} & \multirow[t]{2}{*}{ Significant } \\
\hline & Project & 8.91 & 1.23 & & \\
\hline \multirow[t]{2}{*}{ Jaeger et al., (2020) } & Lecture & 3.57 & 1.71 & \multirow[t]{2}{*}{0.0002} & \multirow[t]{2}{*}{ Significant } \\
\hline & Project & 4.21 & 1.12 & & \\
\hline \multirow[t]{2}{*}{ Worry, (2011) } & Lecture & 2.76 & 0.89 & \multirow[t]{2}{*}{0.0006} & \multirow[t]{2}{*}{ Significant } \\
\hline & Project & 3.10 & 0.72 & & \\
\hline \multirow[t]{2}{*}{ Sawyer, (2013) } & Lecture & 2.47 & 0.92 & \multirow[t]{2}{*}{0.0001} & \multirow[t]{2}{*}{ Significant } \\
\hline & Project & 3.11 & 0.54 & & \\
\hline \multirow[t]{2}{*}{ Deitering, (2016) } & Lecture & 67.34 & 10.39 & \multirow[t]{2}{*}{0.0023} & \multirow[t]{2}{*}{ Significant } \\
\hline & Project & 71.82 & 9.20 & & \\
\hline \multirow[t]{2}{*}{ Overholt, (2017) } & Lecture & 16.30 & 3.45 & 0.0003 & Significant \\
\hline & Project & 18.21 & 3.02 & & \\
\hline Yao et al., (2019) & Lecture & 6.30 & 1.65 & 0.0009 & Significant \\
\hline & Project & 7.69 & 1.08 & & \\
\hline Somani \& Rizvi, & Lecture & 2.90 & 0.61 & 0.0001 & Significant \\
\hline (2018) & Project & 3.17 & 0.45 & & \\
\hline Armstrong- & Lecture & 23.98 & 4.76 & 0.007 & Significant \\
\hline Grodzicki, (2013) & Project & 26.73 & 3.98 & & \\
\hline Tortorella \& & Lecture & 78.43 & 9.23 & 0.0009 & Significant \\
\hline $\begin{array}{l}\text { Cauchick-Miguel, } \\
\text { (2018) }\end{array}$ & Project & 86.30 & 8.97 & & \\
\hline
\end{tabular}

Table.3: Descriptive Statistical Outcomes of Various Studies Reviewed in this Article

The statistical results of table 3 shows that in comparison of project and traditional lecture-based learning strategies, all the studies have shown that projectbased teaching learning strategy is more effective and significant way of learning for the learners. 


\section{RESULT AND DISCUSSION}

In previous many decades, a lot of learning strategies have been applied to improve the learning procedure according to the requirements of learners. Various learning strategies have developed to improve the cognitive skills of the learners (Billing, 2007; Sun, 2013; Nisbet \& Shucksmith, 2017). Many teaching-learning strategies like inquiry-based, project-based, problem-based have proved to be very effective in various disciplines and in different educational level under changing classroom environments (Panasan \& Nuangchalerm, 2010; Silm et al., 2017; Laudano et al., 2020). In this article, a review study has been conducted to compare the project-based and traditional lecturebased learning strategies in various educational levels. The learning outcomes and descriptive statistics of the selected studies are also stated. The review of literature of selected studies indicated that project-based learning strategy is an effective and useful learning strategy to improve the critical and communication skills of the learners.

\section{CONCLUSION}

A review study comprised of project-based and traditional lecture-based learning strategies has been conducted to evaluate the effectiveness of both learning strategies in various disciplines under different educational levels. The learning outcomes and their statistical results are also highlighted. The review of the literature showed that the project-based teaching-learning strategy is one of the most effective learning approaches as compared to other traditional learning strategies in which the learners actively participate in the learning process to improve their academic achievements and cognitive skills.

\section{Conflict of Interest}

No conflict of interest has been found between the authors.

\section{REFERENCES}

Affandi, A., \& Sukyadi, D. (2016). Project-based learning and problem-based learning for EFL students' writing achievement at the tertiary level. Rangsit Journal of Educational Studies, 3(1), 23-40.

Al-Balushi, S. M., \& Al-Aamri, S. S. (2014). The effect of environmental science projects on students' environmental knowledge and science attitudes. International Research in Geographical \& Environmental Education, 23(3), 213-227.

Al-Balushi, S. M., \& Al-Aamri, S. S. (2014). The effect of environmental science projects on students' environmental knowledge and science attitudes. International Research in Geographical and Environmental Education, 23(3), 213-227.

Almanasef, M., Almaghaslah, D., Portlock, J., \& Chater, A. (2020). Qualitative investigation of the flipped classroom teaching approach as an alternative to the traditional lecture. Pharmacy Education, 20, p142-150. 
Anazifa, R. D., \& Djukri, D. (2017). Project-Based Learning and Problem-Based Learning: Are They Effective to Improve Student's Thinking Skills?. Jurnal Pendidikan IPA Indonesia, 6(2), 346-355.

Armstrong-Grodzicki, C. (2013). Meeting the Standards of the Standardized Test: How Does Project-Based Learning Correlate to Traditional Learning in an Advanced Placement English Language and Composition Course?.

Balemen, N., \& Keskin, M. Ö. (2018). The Effectiveness of Project-Based Learning on Science Education: A Meta-Analysis Search. International Online Journal of Education and Teaching, 5(4), 849-865.

Balemen, N., \& Keskin, M. Ö. (2018). The Effectiveness of Project-Based Learning on Science Education: A Meta-Analysis Search. International Online Journal of Education and Teaching, 5(4), 849-865.

Barak, M. (2012). From "doing" to "doing with learning": reflection on an effort to promote self-regulated learning in technological projects in high school. European Journal of Engineering Education, 37(1), 105-116.

Bell, S. (2010). Project-based learning for the 21st century: Skills for the future. The clearing house, 83(2), 39-43.

Bidabadi, N. S., ISFAHANI, A. N., Rouhollahi, A., \& Khalili, R. (2016). Effective teaching methods in higher education: requirements and barriers. Journal of advances in medical education \& professionalism, 4(4), 170.

Billing, D. (2007). Teaching for transfer of core/key skills in higher education: Cognitive skills. Higher education, 53(4), 483-516.

Brassler, M., \& Dettmers, J. (2017). How to enhance interdisciplinary competenceinterdisciplinary problem-based learning versus interdisciplinary project-based learning. Interdisciplinary Journal of Problem-Based Learning, 11(2).

Carter, S. (2016). Traditional vs. project-based learning: The effects on student performance and motivation in honors level mathematics courses.

Chen, C. H., \& Yang, Y. C. (2019). Revisiting the effects of project-based learning on students' academic achievement: A meta-analysis investigating moderators. Educational Research Review, 26, 71-81.

Chidthachack, S., Schulte, M. A., Ntow, F. D., Lin, J. L., Moore, T. J., \& Center, S. E. (2013, October). Engineering Students Learn ABET Professional Skills: A Comparative Study of Project-Based-Learning (PBL) versus Traditional Students. In ASEE North Midwest Section Conference (pp. 17-18).

Chu, S. K. W., Zhang, Y., Chen, K., Chan, C. K., Lee, C. W. Y., Zou, E., \& Lau, W. (2017). The effectiveness of wikis for project-based learning in different disciplines in higher education. The internet and higher education, 33, 49-60.

De Graaff, E., \& Kolmos, A. N. E. T. T. E. (2007). History of problem-based and projectbased learning. In Management of change (pp. 1-8). Brill Sense.

Deitering, S. (2016). Is Project Based Learning a More Effective Way of Teaching Than Traditional Teaching? 
Demian, P., Ruikar, K., Sahu, T., \& Morris, A. (2016). Three-Dimensional Information Retrieval (3DIR): exploiting 3D geometry and model topology in information retrieval from BIM environments. International Journal of 3-D Information Modeling (IJ3DIM), 5(1), 67-78.

Desnylasari, E., Mulyani, S., \& Mulyani, B. (2016). Pengaruh Model Pembelajaran Project Based Learning dan Problem Based Learning Pada Materi Termokimia Terhadap Prestasi Belajar Siswa Kelas XI SMA Negeri 1 Karanganyar Tahun Pelajaran 2015/2016. Jurnal Pendidikan Kimia, 5(1), 134-142.

English, M. C., \& Kitsantas, A. (2013). Supporting student self-regulated learning in problem-and project-based learning. Interdisciplinary journal of problem-based learning, 7(2), 6.

Farashahi, M., \& Tajeddin, M. (2018). Effectiveness of teaching methods in business education: A comparison study on the learning outcomes of lectures, case studies and simulations. The International Journal of Management Education, 16(1), 131142.

Fernandes, S., Mesquita, D., Flores, M. A., \& Lima, R. M. (2014). Engaging students in learning: findings from a study of project-led education. European Journal of Engineering Education, 39(1), 55-67.

Geier, R., Blumenfeld, P. C., Marx, R. W., Krajcik, J. S., Fishman, B., Soloway, E., \& ClayChambers, J. (2008). Standardized test outcomes for students engaged in inquirybased science curricula in the context of urban reform. Journal of Research in Science Teaching: The Official Journal of the National Association for Research in Science Teaching, 45(8), 922-939.

Gholami, M., Moghadam, P. K., Mohammadipoor, F., Tarahi, M. J., Sak, M., Toulabi, T., \& Pour, A. H. H. (2016). Comparing the effects of problem-based learning and the traditional lecture method on critical thinking skills and metacognitive awareness in nursing students in a critical care nursing course. Nurse education today, 45 , 16-21.

Gibbes, M., \& Carson, L. (2014). Project-based language learning: an activity theory analysis. Innovation in Language Learning \& Teaching, 8(2), 171-189.

Gregorius, R. M. (2017). Performance of underprepared students in traditional versus animation-based flipped-classroom settings. Chemistry Education Research and Practice, 18(4), 841-848.

Habok, A. (2015). Implementation of a project-based concept mapping developmental programme to facilitate children's experiential reasoning and comprehension of relations. European Early Childhood Education Research Journal, 23(1), 129-142.

Hafeez, M., Kazmi, Q. A., Tahira, F., Hussain, M. Z., Ahmad, S., Yasmeen, A., ... \& Saqi, M. I. (2020). Impact of School Enrolment Size on Student's Achievements. Indonesian Journal of Basic Education, 3(1), 17-21.

Harris, M. J. (2015). The challenges of implementing project-based learning in middle schools (Doctoral dissertation, University of Pittsburgh). 
Hernández-Ramos, P., \& De La Paz, S. (2009). Learning history in middle school by designing multimedia in a project-based learning experience. Journal of Research on Technology in Education, 42(2), 151-173.

Hsu, P. S., Van Dyke, M., Chen, Y., \& Smith, T. J. (2016). A cross-cultural study of the effect of a graph-oriented computer-assisted project-based learning environment on middle school students' science knowledge and argumentation skills. Journal of Computer Assisted Learning, 32(1), 51-76.

Jaeger, M., Yu, G., \& Adair, D. (2020). Project Based Learning versus Traditional LearningComparing Perspectives of Arab Managers with Chinese Managers. Journal of Problem Based Learning in Higher Education.

Johnson, B., \& Ulseth, R. (2014). Professional competency attainment in a project-based learning curriculum: A comparison of project-based learning to traditional engineering education. In 2014 IEEE Frontiers in Education Conference (FIE) Proceedings (pp. 1-4). IEEE.

Johnson, B., Ulseth, R., Smith, C., \& Fox, D. (2015, October). The impacts of project-based learning on self-directed learning and professional skill attainment: A comparison of project-based learning to traditional engineering education. In 2015 IEEE Frontiers in Education Conference (FIE) (pp. 1-5). IEEE.

Kaldi, S., Filippatou, D., \& Govaris, C. (2011). Project-based learning in primary schools: effects on pupils' learning and attitudes. Education 3-13, 39(1), 35-47.

Karaçalli, S. \& Korur, F. (2014). The effects of project-based learning on students' academic achievement, attitude, and retention of knowledge: the subject of "electricity in our lives". School Science and Mathematics, 114(5), 224-235.

Kizkapan, O., \& Bektas, O. (2017). The Effect of Project Based Learning on Seventh Grade Students' Academic Achievement. International Journal of Instruction, 10(1), 37 54.

Kolmos, A., \& de Graaff, E. (2014). Problem-based and project-based learning in engineering education. Cambridge handbook of engineering education research, 141-161.

Kubiatko, M., \& Vaculová, I. (2011). Project-based learning: characteristic and the experiences with application in the science subjects. Energy Education Science and Technology Part B: Social and Educational Studies, 3(1), 65-74.

Kwon, S. M., Wardrip, P. S., \& Gomez, L. M. (2014). Co-design of interdisciplinary projects as a mechanism for school capacity growth. Improving Schools, 17(1), 54-71.

Laudano, F., Tortoriello, F. S., \& Vincenzi, G. (2020). An experience of teaching algorithms using inquiry-based learning. International Journal of Mathematical Education in Science and Technology, 51(3), 344-353.

Lee, J. S., Blackwell, S., Drake, J., \& Moran, K. A. (2014). Taking a leap of faith: Redefining teaching and learning in higher education through project-based learning. Interdisciplinary Journal of Problem-Based Learning, 8(2), 2. 
Lisa, D., Kristin, F., Karen, S. F., Kaori, G., \& Jennifer, R. (2018). Evaluating impact: a comparison of learning experiences and outcomes of students completing a traditional versus multidisciplinary, Project-Based Introductory Statistics Course. International Journal of Education, Training and Learning, 2(1).

Mann, L., Chang, R., Chandrasekaran, S., Coddington, A., Daniel, S., Cook, E., ... \& Smith, T. D. (2020). From problem-based learning to practice-based education: A framework for shaping future engineers. European Journal of Engineering Education, 1-21.

Maqbool, S., Ismail, S. A. M. B. M., Maqbool, S., \& Hassan, S. U. (2018). Effects of Traditional Lecture Method and Multi-Sensory Approach on ELT Learners at Graduate Level. International Journal of Academic Research in Progressive Education and Development, 7(4), 488-505.

Molbaek, M. (2018). Inclusive teaching strategies-dimensions and agendas. International Journal of Inclusive Education, 22(10), 1048-1061.

Nainggolan, B., Hutabarat, W., Situmorang, M., \& Sitorus, M. (2020). Developing Innovative Chemistry Laboratory Workbook Integrated with Project-Based Learning and Character-Based Chemistry. International Journal of Instruction, 13(3), 895-908.

Naji, K. K., Ebead, U., Al-Ali, A. K., \& Du, X. (2020). Comparing Models of Problem and Project-Based Learning (PBL) Courses and Student Engagement in Civil Engineering in Qatar. Eurasia Journal of Mathematics, Science and Technology Education, 16(8), em1867.

Nelson, A.E., 2017. Methods faculty use to facilitate nursing students' critical thinking. Teach. Learn. Nurs. 12 (1), 62-66. https://doi.org/10.1016/j.teln.2016.09.007.

Nisbet, J., \& Shucksmith, J. (2017). Learning strategies. Routledge.

Overholt, K. B. (2017). Academic Achievement of 6th Grade Students in a Social Studies Classroom Implementing Traditional vs Project-Based Learning.

Palis, A. G., \& Quiros, P. A. (2014). Adult learning principles and presentation pearls. Middle East African journal of ophthalmology, 21(2), 114.

Panasan, M., \& Nuangchalerm, P. (2010). Learning Outcomes of Project-Based and Inquiry-Based Learning Activities. Online Submission, 6(2), 252-255.

Pinter, R., \& Cisar, S. M. (2018). Measuring Team Member Performance in Project Based Learning. Journal of Applied Technical and Educational Sciences, 8(4), 22-34.

Saira, A. F., \& Hafeez, M. (2020). Assessment of Student's Academic Achievement by Flipped Classroom Model and Traditional Lecture Method. Global Educational Studies Review, 4, 10-19.

Sari, I. K. (2018). The effect of problem-based learning and project-based learning on the achievement motivation. Jurnal Prima Edukasia, 6(2), 129-135.

Sarıhan, A., Oray, N. C., Güllüpınar, B., Yanturali, S., Atilla, R., \& Musal, B. (2016). The comparison of the efficiency of traditional lectures to video-supported lectures 
within the training of the Emergency Medicine residents. Turkish journal of emergency medicine, 16(3), 107-111.

Sawyer, G. L. (2013). The effects of traditional teaching methods, project-based learning, and a blended teaching style on elementary students. Trevecca Nazarene University.

Senthamarai, S. (2018). Interactive teaching strategies. Journal of Applied and Advanced Research, 3(1), S36-S38.

Silm, G., Tiitsaar, K., Pedaste, M., Zacharia, Z. C., \& Papaevripidou, M. (2017). Teachers' Readiness to Use Inquiry-Based Learning: An Investigation of Teachers' Sense of Efficacy and Attitudes toward Inquiry-Based Learning. Science Education International, 28(4), 315-325.

Sivarajah, R. T., Curci, N. E., Johnson, E. M., Lam, D. L., Lee, J. T., \& Richardson, M. L. (2019). A review of innovative teaching methods. Academic radiology, 26(1), 101-113.

Somani, R., \& Rizvi, M. (2018). Project Based Learning over Traditional Method of Language Teaching: A Quasi Experiment Design in EFL Classrooms. Literacy Information and Computer Education Journal (LICEJ), 9(2), 2895-2904.

Stanescu, M. M. (2017). The advantages of using sensors in Project-Based Learning of sciences. In Proceedings of the 12th International Conference on Virtual learning (pp. 498-503).

Strubbe, L. E., Madsen, A. M., McKagan, S. B., \& Sayre, E. C. (2020). Beyond teaching methods: Highlighting physics faculty's strengths and agency. Physical Review Physics Education Research, 16(2), 020105.

Sultana, M., \& Zaki, S. (2015). Proposing Project Based Learning as an alternative to traditional ELT pedagogy at public colleges in Pakistan. International Journal for Lesson and Learning Studies.

Sun, L. (2013). The Effect of Meta-cognitive Learning Strategies on English Learning. Theory \& Practice in Language Studies, 3(11).

Tang, Y. M., Au, K. M., Lau, H. C., Ho, G. T., \& Wu, C. H. (2020). Evaluating the effectiveness of learning design with mixed reality (MR) in higher education. Virtual Reality, 24(4), 797-807.

Tavoosy, Y., \& Jelveh, R. (2019). Language teaching strategies and techniques used to support students learning in a language other than their mother tongue. International Journal of Learning and Teaching, 11(2), 77-88.

Tortorella, G., \& Cauchick-Miguel, P. (2018). Combining traditional teaching methods and PBL for teaching and learning of lean manufacturing. IFAC-Papers Online, 51(11), 915-920.

Ulya, F., RC, A. R., \& Sulistyorini, S. (2020). The Effectiveness of Project-Based Learning Model and Talking stickType of Cooperative Learning Model on the Quran-Hadith Subject Learning Outcomes. Innovative Journal of Curriculum and Educational Technology, 9(2), 87-93. 
Usarov, J. (2019). Using Teaching Methods for Development Student Competencies. International Journal of Progressive Sciences and Technologies, 15(1), 272-274.

Worry, V. A. (2011). A comparison of high school geometry student performance and motivation between traditional and project-based instruction techniques (Doctoral dissertation, Walden University).

Yao, J., Sun, H., Tian, Y., \& Gu, H. (2019). Project-Based Learning in Chinese Middle-School Students Is More Effective than the Traditional Teaching Method: An Experimental Study.

Yli-Panula, E., Jeronen, E., Lemmetty, P., \& Pauna, A. (2018). Teaching methods in biology promoting biodiversity education. Sustainability, 10(10), 3812.

Yusupov, R. (2020). Modern informatics and its teaching methods. Архив Научных Публикаций JSPI, 1-10.

Zafirov, C. (2013). New challenges for the project-based learning in the digital age. Trakia Journal of Sciences, 11(3), 298-302. 